\title{
W JAKI SPOSÓB BADAĆ SEJSMITY? PRZEGLĄD METOD BADAWCZYCH
}

\author{
How to study seismites? A review of research methods
}

\author{
SZYMON BELZYT*, MAŁGORZATA PISARSKA-JAMROŻY*
}

\begin{abstract}
Zarys treści. Propagacja, wywołanej trzęsieniem ziemi, fali sejsmicznej w uwodnionych nieskonsolidowanych osadach drobnoziarnistych powodować może ich upłynnienie. W efekcie tego procesu powstać mogą warstwy zawierające struktury deformacyjne zwane sejsmitami. Zaproponowanie sejsmicznej genezy warstw zdeformowanych opiera się na zastosowaniu kryteriów rozpoznawczych. W tym celu konieczne jest: (1) przeprowadzenie analizy litofacjalnej osadów występujących w analizowanym profilu; (2) szczegółowe opisanie: deformacji, z uwzględnieniem ich rozmieszczenia w profilu i w obrębie zdeformowanej ławicy, rozciągłości poziomej, zróżnicowania przestrzennego, geometrii, tekstury i struktury osadów zaangażowanych w deformacje, osadów otaczających oraz zmiany rozkładu przestrzennego struktur deformacyjnych przy wykorzystaniu ścięcia poziomego i ukośnego; (3) wytypowanie struktur, które mogły powstać w efekcie upłynnienia i porównanie ich ze współcześnie tworzącymi się deformacjami związanymi ze wstrząsami sejsmicznymi; (4) rozpoznanie budowy geologicznej podłoża skalnego, w tym m.in. opis aktywności uskoków; (5) dyskusja innych mechanizmów, które mogły odpowiadać za powstanie deformacji; (6) określenie czasu powstania struktur deformacyjnych.
\end{abstract}

Slowa kluczowe: deformacje w osadach nieskonsolidowanych, paleosejsmologia, trzęsienia ziemi

\begin{abstract}
Earthquake-triggered seismic wave propagation can induce liquefaction of water-saturated unconsolidated finegrained clastic sediments. As a result, layers with soft-sediment deformation structures called seismites can be formed. To propose a seismic origin of the layer, it should meet recognition criteria. Therefore, it is necessary to provide (1) a lithofacies analysis of the sediments in the studied section; (2) a detailed description of deformation structures including their position in the sedimentological log as well as within the deformed layer, lateral extent and continuity, geometry, texture and structure of both deformed and host sediments, spatial distribution and heterogenity of deformation structures in the plan view as well as an oblique view; (3) identification of structures that could have been formed during a liquefaction process and a comparison with those that recently occurred in tectonically active zones as an earthquake effect; (4) a subsurface geological structure recognition, particularly the presence and activity of faults; (5) discussion and elimination of all other possible triggers that could have caused sediment deformation; (6) estimation of the age of the deformation.
\end{abstract}

Key words: soft-sediment deformation structures, palaeoseismology, earthquakes

\section{Wprowadzenie}

Sejsmity to warstwy skał osadowych, które zostały zdeformowane w wyniku trzęsień ziemi (Seilacher 1969). Deformacje sejsmiczne osadów rozwijają się bezpośrednio po depozycji, ale przed rozpoczęciem procesów lityfikacyjnych. Sejsmity są najczęściej spotykane w drobnoziarnistych osadach jeziornych i rzecznych różnego wieku - od archaicznych po współczesne (np. Obermeier 1996, 2009; Obermeier i in. 2005; Rodríguez-López i in. 2007; Van Loon 2009; Põldsaar, Ainsaar 2015; Quigley i in. 2016; Shanmugam 2016; Wojewoda i in. 2016; Tuttle i in. 2017).
Mechanizmem spustowym (ang. trigger mechanism) bezpośrednio wywołującym propagację fali może być m.in. uderzenie meteorytu, erupcja wulkanu, obciążenie lub odciążenie pokrywą lodową (ang. glacio-isostatic rebound), gwattowna depozycja i obciążenie niżej leżącego osadu, tektonika solna, ruch masowy, oddziaływanie falowania, ekspulsje gazów, endogeniczne trzęsienia ziemi. Podstawowym kryterium rozpoznawczym sejsmitów jest występowanie wewnątrz nich struktur deformacyjnych (ang. soft-sediment deformation structures, skrót: SSDS). Warto w tym miejscu zaznaczyć, że termin sejsmit i SSDS nie są terminami równoznacznymi, tzn. SSDS jest terminem szerszym i odnosi się do wszelkich deformacji

\footnotetext{
* Uniwersytet im. Adama Mickiewicza, Instytut Geologii, ul. Bogumiła Krygowskiego 12, 61-680 Poznań; e-mail: szymon.belzyt@amu.edu.pl
} 
powstałych w efekcie różnych procesów, np. peryglacjalnych, ruchów masowych etc.

Bezpośrednią przyczyną powstania sejsmitów jest propagacja sejsmicznych fal poprzecznych S (ang. secondary body seismic waves, shear waves), które powodują zmianę położenia cząstek osadu zgodną z kierunkiem rozchodzenia się fali, czego wynikiem jest upłynnienie (ang. liquefaction) osadu (Allen 1982, 1986; Obermeier 1996). Upłynnienie to według Jaroszewskiego i in. (1985) i Zielińskiego (2014) przejście luźnego osadu piaszczystego lub pylastego, pod wpływem przyłożonego naprężenia (np. wstrząsu lub obciążenia), w płynną masę. Dochodzi do tego wskutek wzrostu ciśnienia wód porowych, które niszczy kontakty międzyziarnowe i powoduje utratę wytrzymałości na ścinanie (Casagrande 1976; Allen 1982, 1986; Owen 1996; Moretti i in. 1999). Wówczas osad wykazuje właściwości charakterystyczne dla cieczy, zachowując jednocześnie swoją objętość. W takich warunkach woda ani nie dopływa do osadu, ani z niego nie uchodzi, a zasadniczym mechanizmem unoszenia i przemieszczenia ziaren jest ciśnienie wód porowych.

Aby daną warstwę (lub grupę warstw) można było nazywać sejsmitem, musi ona zostać poddana szczegółowej analizie sedymentologicznej i strukturalnej oraz spełnić szereg kryteriów klasyfikacyjnych. Według obecnego stanu wiedzy, za wskaźniki rozpoznawcze sejsmicznej genezy deformacji w nieskonsolidowanych osadach przyjmowane są kryteria zaproponowane w pracach Owena i Morettiego (2008), Owena i in. (2011) oraz Morettiego i Van Loona (2014). Głównym celem niniejszego opracowania jest syntetyczne zestawienie metod badawczych wykorzystywanych przy analizie zapisu aktywności sejsmicznej w osadach klastycznych.

\section{Kryteria identyfikacji sejsmitów}

Prawidłowe zaplanowanie prac badawczych, na podstawie których prowadzone jest rozpozna- nie struktur deformacyjnych wywołanych falą sejsmiczną, rozpoczyna się od identyfikacji struktur, które mogły powstać $\mathrm{w}$ wyniku przejścia fali. Do struktur deformacyjnych powstałych w efekcie upłynnienia i uwodnienia należą: (1) struktury odwodnieniowe (ucieczki wody, ang. dewatering structures, water/fluid escape structures), np. dajki (ang. clastic dykes) i wulkany klastyczne (ang. clastic volcanoes), kanały ucieczkowe (ang. column structures, pillars) oraz struktury miseczkowe (ang. dish structures); (2) struktury niestatecznego warstwowania gęstościowego, np. tzw. load structures (loadcasts, pseudonodules), tzw. ball i pillows oraz związane $\mathrm{z}$ nim struktury płomieniowe (ang. flame structures); (3) deformacje kruche, np. uskoki, zręby i rowy oraz brekcje (rys. 1).

Ponadto, za sejsmiczną genezą deformacji może przemawiać ich duże zróżnicowanie geometryczne w obrębie danej warstwy. Istotnym argumentem $\mathrm{w}$ dyskusji o genezie deformacji może być obserwacja analogicznych struktur powstających w obrębie upłynnionych drobnoklastycznych osadów w rejonach współcześnie aktywnych sejsmicznie. Są to m.in. wulkany i dajki piaszczyste lub błotne oraz kanały odwodnieniowe, sięgające często powierzchni terenu. Według najnowszych danych obserwacyjnych do upłynnienia osadów dochodzi przy zwierciadle wód podziemnych, ustalonym na $1 \mathrm{~m}$ p.p.t., w obrębie luźnych osadów drobnopiaszczystych o minimalnie 2-metrowej miąższości (m.in. Quigley $\mathrm{i}$ in. 2016; Tuttle i in. 2017).

Kolejnym kryterium jest zasięg warstw zdeformowanych. SSDS powinny być obserwowane lateralnie w obrębie całego sejsmitu, choć styl deformacji przestrzennie może się zmieniać. W wielu opracowaniach, jeśli warunki geologiczne na to pozwalają, stosuje się metodę korelacji sejsmitów występujących w obrębie sąsiadujących ze sobą odsłonięć lub obecnych w rdzeniach osadów pochodzących z wierceń (m.in. Mörner 2005; Ezquerro i in. 2015; Põldsaar, Ainsaar 2015).

Rys. 1. Struktury deformacyjne w osadach nieskonsolidowanych powstające w efekcie działania upłynnienia

A - naprzemiennie występujące zdeformowane i niezdeformowane osady („,kanapkowe” ułożenie, stanowisko Valmiera na Łotwie); B - struktury powstałe w efekcie upłynnienia, rozrywające wyżej leżący laminowany osad piaszczysty (stanowisko Seredzius Slinktis na Litwie); C - struktury niestatecznego warstwowania gęstościowego tzw. loadcasts, wskazujące na wieloetapowość procesu grzęźnięcia, otoczone upłynnionym osadem, który częściowo zerodował brzeżne części struktur typu loadcasts (stanowisko Dyburiai na Litwie); D - piaszczyste struktury typu balls i pillows otoczone osadem mułowym (stanowisko Dwasieden w Niemczech); E - dajka klastyczna wypełniona mułowym osadem występująca w drobnoziarnistych osadach piaszczystych (stanowisko Seredzius Slinktis na Litwie); F - chaotycznie rozmieszczone struktury deformacyjne małej skali typu pseudonodules, balls i pillows oraz porozrywane fragmenty lamin drobnopiaszczystych (stanowisko Weisser Berg w Niemczech); G - piaszczyste struktury typu loadcasts oraz struktury związane z upłynnieniem - kanały ucieczkowe w obrębie izolowanej warstwy o wyraźnym stropie i spągu (stanowisko Dwasieden w Niemczech) 

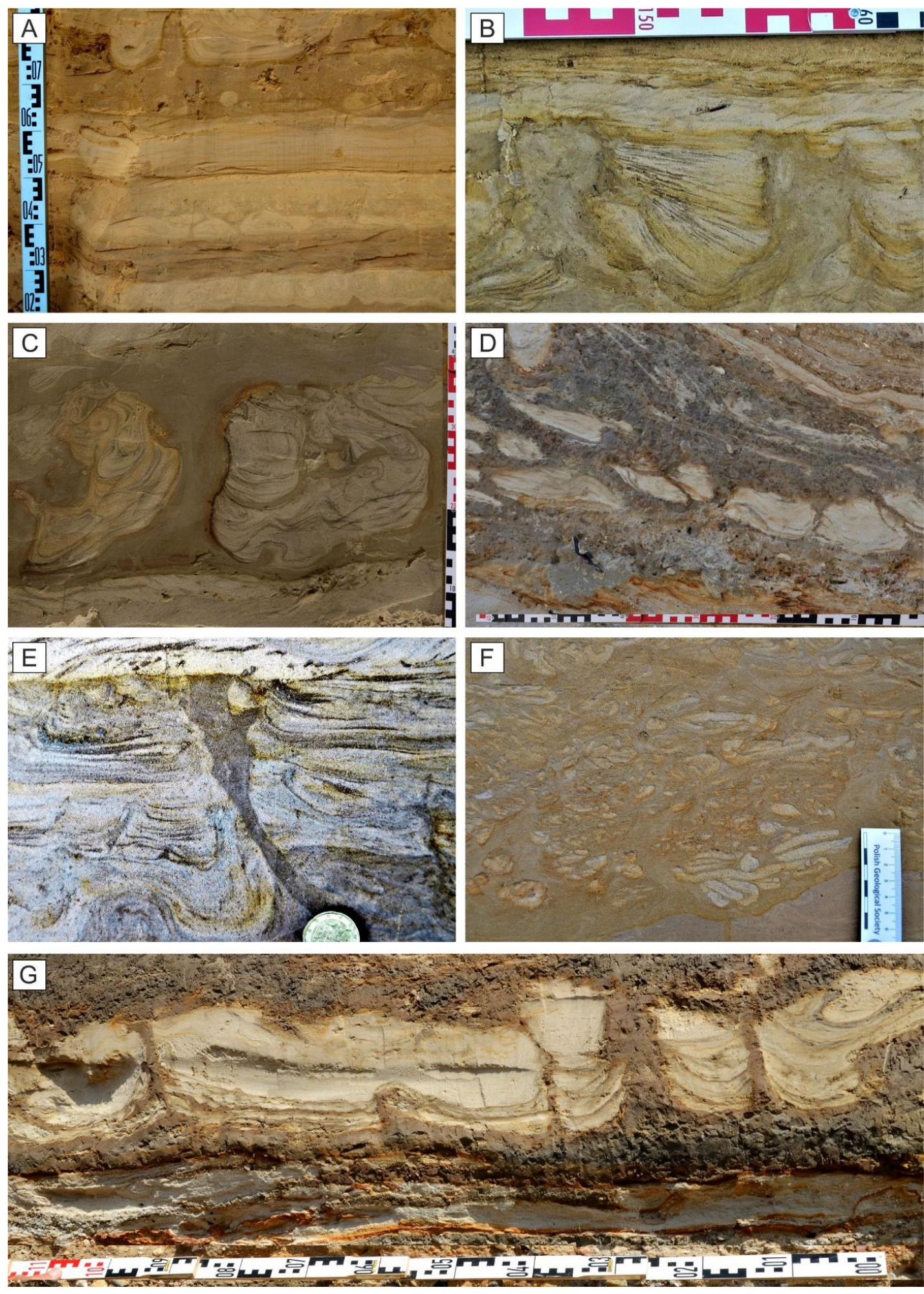

Liquefaction-induced soft-sediment deformation structures

A - sandwiched-like deformed and undeformed sediments (Valmiera site in Latvia); B - liquefaction-induced structures disintegrating the overlying laminated sandy layer (Seredzius Slinktis site in Lithuania); C - unstable density gradient structures - load casts indicating multi-stage sinking within liquefied sediment that partly eroded the outer parts of the loadcasts (Dyburiai site in Lithuania); D - sandy balls and pillows within muddy deposits (Dwasieden site in Germany); E - dewatering (water escape) structure - clastic dyke infilled by mud intruding into the fine sand layer (Seredzius Slinktis site in Lithuania); F - chaotic distribution of small-scale pseudonodules, ball and pillows and disintegrated sandy laminae fragments (Weisser Berg site in Germany); G - sandy loadcasts and dewatering (water escape) structures - dewatering pipes within an isolated layer with clearly visible base and top (Dwasieden site in Germany) 
Częstym, choć nie obligatoryjnym, kryterium jest powtarzalność graniczących ze sobą warstw zawierających deformacje oraz niezdeformowanych (tzw. kanapkowe ułożenie, ang. sandwiched-like; rys. 1A). Na przykład Van Loon i in. (2016) w łotewskich stanowiskach Valmiera i Rakuti stwierdzili obecność kolejno 7 i 12 poziomów sejsmitów przewarstwionych osadami niezaburzonymi, co pozwoliło na wnioskowanie o częstotliwości trzęsień ziemi związanych z glaciizostatycznym odprężeniem tego obszaru w trakcie ostatniej deglacjacji.

Ważne kryterium stanowi także lokalizacja warstw zawierających deformacje w pobliżu uskoków, które są aktywne współcześnie bądź mogły być miejscem gwałtownej relaksacji naprężeń w przeszłości geologicznej. Położenie epicentrum trzęsienia ziemi ma istotny wpływ na rozmieszczenie oraz intensywność procesów upłynnienia, a w związku z tym na występowanie deformacji. Maksymalna zaobserwowana i opisana w literaturze odległość od epicentrum wynosi $40 \mathrm{~km}$, a minimalną magnitudę niezbędną do powstania struktur deformacyjnych szacuje się na 4-5 (Ambraseys 1988; Papadopoulos, Lefkopoulos 1993; Galli 2000).

\section{Metody badań sejsmitów w osadach nieskonsolidowanych}

Metodami stosowanymi przy badaniu deformacji osadów klastycznych, ze szczególnym uwzględnieniem struktur powstałych w efekcie propagacji fali sejsmicznej, są: (1) analiza litofacjalna profilu, w którym występują deformacje, pozwalająca określić paleośrodowisko depozycji; (2) szczegółowy opis deformacji, uwzględniający ich rozmieszczenie $w$ profilu oraz w obrębie zdeformowanej ławicy, ewentualną powtarzalność w pionie, rozciągłość poziomą zdeformowanej ławicy, zróżnicowanie przestrzenne typów deformacji, geometrię deformacji w tym również opis $3 \mathrm{D}$, opis struktury osadów zaangażowanych $\mathrm{w}$ deformacje oraz osadów otaczających, zarówno w skali makro, jak i mikro (analiza szlifów), uziarnienie, zarówno wewnątrz deformacji, jak i osadów otaczających oraz zmianę rozkładu przestrzennego struktur deformacyjnych $\mathrm{w}$ ścięciu poziomym i ukośnym; (3) wytypowanie struktur, które mogły powstać w efekcie upłynnienia i porównanie ich ze współcześnie tworzącymi się deformacjami związanymi ze wstrząsami sejsmicznymi; (4) rozpoznanie budowy geologicznej podłoża skal- nego, w tym opis aktywności uskoków; (5) dyskusja pozostałych prawdopodobnych mechanizmów, które mogłyby odpowiadać za powstanie deformacji, np. glacitektonicznych, tektoniki solnej, kriotektoniki, ruchów masowych, uderzeń meteorytów; (6) wykonanie datowań osadów niezdeformowanych występujących w bezpośrednim kontakcie z osadami zdeformowanymi.

Zaproponowane metody badawcze usystematyzowano celowo w sposób niestandardowy, tzn. pogrupowano je ze względu na własności przedmiotu badań, istotności cech i kolejności ich wykonywania. Ponadto przedstawiono krótką dyskusję nad celowością wykorzystania konkretnych metod badawczych. Zgodnie ze standardowym podziałem metod badawczych w metodach terenowych mieścić się będą - analiza litofacjalna osadów, opis struktur deformacyjnych i osadów bezpośrednio je otaczających oraz określenie czasu powstania deformacji; w metodach laboratoryjnych - opis struktur deformacyjnych i osadów bezpośrednio je otaczających oraz określenie czasu powstania deformacji; a w metodach kameralnych - analiza litofacjalna osadów, opis struktur deformacyjnych i osadów bezpośrednio je otaczających, rozpoznanie struktur deformacyjnych związanych z procesem upłynnienia, rozpoznanie budowy geologicznej podłoża skalnego oraz dyskusja nad pozostałymi czynnikami, które mogłyby odpowiadać za powstanie deformacji.

\section{Analiza litofacjalna osadów}

Analiza litofacjalna osadów stanowi jedną $\mathrm{z}$ podstawowych metod stosowanych $\mathrm{w}$ sedymentologii i opisywanie jej w tym miejscu jest zbędne (por. Miall 1977; Zieliński 1992, 1995; Zieliński, Pisarska-Jamroży 2012). Dokładny opis litofacjalny, a następnie interpretacja genetyczna warunków środowiska jest niezbędna do odczytania prawidłowych implikacji paleogeograficznych. Powszechnie wiadomo, że struktury deformacyjne spowodowane rozchodzeniem fali sejsmicznej zapisują się przede wszystkim w osadach uwodnionych i udział wody jest niezbędny do ich powstania (Lowe 1976; Allen 1982; Rossetti 1999; Owen 1996; Van VlietLanoë i in. 2004). Sejsmity występują przede wszystkim w osadach dobrze lub średnio wysortowanych piasków średnio- i drobnoziarnistych oraz pylastych (Obermeier 1996, 2009). W osadach drobniejszych od wymienionych kohezja w znaczący sposób utrudnia przemieszczanie 
ziaren, a w osadach gruboziarnistych ziarna są zazwyczaj zbyt ciężkie, by mogły być przemieszczane dzięki wodzie porowej (Crespellani $i$ in. 1988; Moretti i in. 1999).

Sejsmiczne struktury deformacyjne odnotowywane są przede wszystkim w klastycznych osadach limnicznych i glacilimnicznych oraz w dystalnych, drobnopiaszczystych częściach sandrów (Mörner 1991, 2013; Wu, Johnson 2000; Van Vliet-Lanoë i in. 2004; Hoffmann, Reicherter 2012; Brandes i in. 2012; Van Loon, Pisarska-Jamroży 2014; Van Loon i in. 2016).

\section{Opis struktur deformacyjnych i osadów bezpośrednio je otaczających}

Badanie deformacji indukowanych sejsmicznie powinno uwzględniać ich szczegółowy opis w danej warstwie. Deformacje takie występują w obrębie jednej lub kilku warstw (por. Owen, Moretti 2011), a ich typową cechą jest „kanapkowe” ułożenie (rys. 1A), stąd istotne wydaje się zwrócenie uwagi na wszelkie regularności $\mathrm{w}$ rozmieszczeniu ławic zaangażowanych $\mathrm{w}$ deformacje. Ważna jest także rozciągłość pozioma warstwy zdeformowanej, zwłaszcza, że wielu autorów podaje ją jako kluczową przy rozpoznawaniu sejsmitów (Van Loon 2009; Owen, Moretti 2011; Alsop, Marco 2011; Van Loon, Maulik 2011; Brandes i in. 2012; Brandes, Winsemann 2013; Tian i in. 2015, 2016). Ponadto przy odpowiednio dużej rozciągłości sejsmitu (kilkadziesiąt metrów), możliwe jest prześledzenie w jego obrębie zróżnicowania przestrzennego typów i geometrii deformacji (Van Loon, Pisarska-Jamroży 2014). Na tej podstawie wielu autorów określa położenie potencjalnego epicentrum (m.in. Guiraud, Plaziat 1993; Obermeier 1996).

Metody badań deformacji sejsmicznych uwzględniać powinny szczegółowy opis kształtu i cech morfometrycznych deformacji w obrazie 3D. Konieczne jest zwrócenie uwagi na charakter granic pomiędzy strukturami deformacyjnymi a otaczającym je osadem. Opis ten powinien być wykonany zarówno w makro-, jak i mikroskali. Znaczenie ma nie tylko kształt poszczególnych deformacji, ale i powtarzalność cech, takich jak nachylenie czy położenie w obrębie ławicy, tzn. odległość od spągu i stropu.

Istotny jest opis struktury wewnętrznej stwierdzonej w deformacjach oraz kąt zawarty między laminami występującymi wewnątrz struktury a jej zewnętrznym kształtem, w tym również opis współkształtności laminacji lub jej braku w ramach deformacji plastycznych typu load structures (np. loadcasts, pseudonodules; rys. $1 \mathrm{C}, \mathrm{D}, \mathrm{F}, \mathrm{G})$. Laminacja występująca wewnątrz plastycznych struktur grzęznących o zróżnicowanym ukierunkowaniu może wskazywać na sukcesywne etapy grzęźnięcia jednych struktur typu loadcast w drugie, co z kolei może być powodowane występowaniem kolejnych wstrząsów, w tym m.in. wtórnych (ang. aftershocks; Van Loon $\mathrm{i}$ in. 2016). Konieczny jest także opis struktur znajdujących się $\mathrm{w}$ osadach otaczających struktury deformacyjne, ze szczególnym uwzględnieniem tych, które mogły powstać $\mathrm{w}$ trakcie propagacji indukowanej sejsmicznie fali typu S, czyli wszelkich struktur wskazujących na ruch uwodnionego osadu w kierunku od spągu do stropu (por. Lowe 1976; Allen 1982). Analizom strukturalnym powinny towarzyszyć analizy tekstualne. Często, ze względu na wielkość struktur deformacyjnych, próbki do analiz granulometrycznych są na tyle małe, iż możliwe jest przeprowadzenie jedynie laserowej analizy uziarnienia. Próby powinny być pobrane zarówno z deformacji, jak i osadów otaczających.

Ze względu na inwazyjność badania, jednym $\mathrm{z}$ ostatnich etapów analizy struktur deformacyjnych, jest opis zmienności rozkładu przestrzennego struktur deformacyjnych $\mathrm{w}$ obrazie $3 \mathrm{D}$, w przekroju od stropu aż po spąg zdeformowanej warstwy.

\section{Rozpoznanie struktur deformacyjnych związanych z procesem upłynnienia}

Rozpoznanie struktur związanych z procesem upłynnienia, które wskazują na ruch uwodnionego osadu w górę (struktury iniekcyjne; ang. injection structures) (por. Rossetti 1999; Van Vliet-Lanoë i in. 2004), a także struktur, które uznaje się jako towarzyszące - jak np. struktur płomieniowych (ang. flame structures) jest kluczowe przy rozpatrywaniu sejsmicznej genezy deformacji. Wprawdzie nie wszystkie struktury związane z upłynnieniem wskazują na trzęsienie ziemi, ale ich brak pozwala wykluczyć taką genezę. Wśród struktur iniekcyjnych, które jednocześnie są strukturami odwodnieniowymi wyróżnić można: struktury kolumnowe o różnych rozmiarach (ang. column structures, pillars), dajki klastyczne (ang. clastic dykes) i wulkany 
piaszczyste (ang. sand volcanoes). Rozpoznanie tych struktur powinno być także poszerzone o opis teksturalno-strukturalny osadów je wypełniających w makro- i mikroskali oraz o wskazanie ich potencjalnego źródła. Pomocna w tym przypadku może być analiza płytek cienkich, ponieważ dostarcza szczegółowych informacji zarówno o interakcji ziaren na granicach struktur deformacyjnych jak i wewnętrznej ich organizacji. Ponadto należy zwrócić uwagę na kontakt danej struktury $\mathrm{z}$ osadami otaczającymi, w szczególności z wszelkimi deformacjami lub ugięciami lamin w strefach granicznych.

\section{Rozpoznanie budowy geologicznej podłoża skalnego}

Interpretacja struktur sejsmicznych nie może być oderwana od regionalnej analizy budowy geologicznej zarówno przypowierzchniowej, jak i wgłębnej, w tym jednostek strukturalnych, stref dyslokacyjnych, ewentualnej obecności struktur solnych, zasięgu występowania lokalnych deformacji glacitektonicznych oraz kierunków współczesnych naprężeń w skorupie ziemskiej. Ponadto czynnikami, mogącymi spowodować przekroczenie krytycznych naprężeń w skorupie ziemskiej i reaktywację uskoków na obszarach, które były zlodowacone $\mathrm{w}$ plejstocenie, mogą być m.in. naprężenia resztkowe związane $\mathrm{z}$ orogenezą alpejską (m.in. Jarosiński 2010), aktywacja struktur solnych (m.in. Piotrowski 1999) oraz obciążenie lub odciążenie spowodowane zmianami zasięgu pokrywy lodowej (Mörner 1991; Grollimund, Zoback 2000; Zoback, Grollimund 2001).

Najczęściej sejsmity są obserwowane w strefach aktywnych tektonicznie. Koncentrują się często przy powierzchni, w pobliżu zaznaczających się w morfologii aktywnych struktur uskokowych (Obermeier 1996, 2009; McCalpin, Nelson 2009). Warto jednak zaznaczyć, że osad może ulec upłynnieniu również wskutek propagacji fali o źródle (hipocentrum) znajdującym się na głębokości przekraczającej kilkadziesiąt kilometrów (Mörner 1991; Grollimund, Zoback 2000; Zoback, Grollimund 2001; Hoffmann, Reicherter 2012; Brandes i in. 2012). Epicentrum trzęsienia ziemi, które zapisało się w postaci deformacji sejsmicznych, mogło być zlokalizowane maksymalnie w odległości do kilkudziesięciu kilometrów od miejsca obserwacji sejsmitu (Ambraseys 1988; Papadopoulos, Lefkopou- los 1993; Obermeier 1996; Galli 2000; Owen, Moretti 2008; Owen i in. 2011).

Wnioskowanie o występowaniu i ewentualnej aktywności uskoku w przeszłości powinno być przeprowadzone na podstawie syntezy dokumentacji kartograficznej, modeli geologicznych (powierzchniowych i odkrytych), map geomorfologicznych, strukturalnych, geofizycznych, danych sejsmicznych i otworowych oraz bazy danych World Stress Map.

\section{Dyskusja nad pozostałymi czynnikami, które mogłyby odpowiadać za powstanie deformacji}

Aby uznać warstwę zdeformowaną za sejsmit należy wyeliminować pozostałe możliwe mechanizmy spustowe. Według klasyfikacji Allena (2003) do głównych mechanizmów spustowych, powodujących rozwój deformacji klastycznych, należą: (1) trzęsienia ziemi, o co najmniej umiarkowanej magnitudzie $(M>4-5)$; (2) regionalne zjawiska niezwiązane $\mathrm{z}$ aktywnością sejsmiczną, które powodują wzrost ciśnienia porowego wewnątrz osadu; (3) pojawienie się czynnika powodującego gwałtowną akumulację osadu o grubszej granulacji (np. podwodne prądy gęstościowe, katastrofalne powodzie lodowcowe); (4) zmiany ciśnienia hydrostatycznego i wytrzymałości na ścinanie, związane z rozwijającym się falowaniem morskim lub propagacją fal tsunami; (5) zmiany ciśnienia hydrostatycznego i wytrzymałości na ścinanie, związane z przepływem turbulentnym; (6) sezonowe topnienie warstwowanych osadów fluwialnych w warunkach peryglacjalnych.

Powstanie deformacji może być wynikiem zarówno jednego procesu, jak i efektem nałożenia się kilku współwystępujących lub następujących po sobie. Dokonując analizy, należy wziąć pod uwagę m.in. cechy teksturalno-strukturalne i genezę osadu, charakter warstwy zdeformowanej oraz samych deformacji, nachylenie stoku, paleogeografię oraz lokalną i regionalną budowę geologiczną. Prawidłowa metodycznie procedura eliminacyjna powinna skutkować potwierdzeniem sejsmicznej genezy deformacji jako najbardziej prawdopodobnej lub zaproponowaniem innego procesu (Alfaro i in. 2002; Brandes, Winsemann 2013; Pisarska-Jamroży, Weckwerth 2013). 


\section{Określenie czasu powstania deformacji}

W praktyce badawczej określenie czasu powstania deformacji sejsmicznych, powstających przy powierzchni terenu, sprowadza się do zaproponowania ram czasowych, tzn. ustala się wiek maksymalny powstania sejsmitu, czyli wiek niezdeformowanego osadu leżącego bezpośrednio poniżej oraz wiek minimalny, otrzymany $\mathrm{z}$ datowania bezpośrednio nadległych niezdeformowanych osadów (McCalpin, Nelson 2009). W literaturze opisywany jest również pobór materiału do datowania $\mathrm{z}$ warstw zdeformowanych, które uległy upłynnieniu (m.in. Brandes $\mathrm{i}$ in. 2012). Biorąc jednak pod uwagę fakt, że do upłynnienia może dochodzić na głębokości 5-10 metrów, opróbowany bezpośrednio nadległy, niezdeformowany osad może być starszy od wieku aktywności sejsmicznej (McCalpin, Nelson 2009).

Określając wiek deformacji sejsmicznych posiłkować się można wiekiem osadów deponowanych podczas zlodowaceń (m.in. Van Vliet-Lanoë i in. 1997; Hoffmann, Reicherter 2012; Van Loon i in. 2016), jak i bezwzględnymi datowaniami luminescencyjnymi (m.in. Brandes i in. 2012; Van Loon, Pisarska-Jamroży 2014). W obu jednak przypadkach należy zwrócić uwagę na dwa rodzaje niepewności wyniku niedokładności związanych z metodą pomiarowa oraz niepewności interpretacyjnych związanych z głębokością występowania osadów podatnych na upłynnienie w czasie przejścia fali sejsmicznej.

\section{Podsumowanie}

1. Wywołana trzęsieniem ziemi propagacja fali sejsmicznej, w specyficznych warunkach, powodować może upłynnienie nieskonsolidowanych osadów drobnoklastycznych. Zapisem tego procesu może być warstwa zaburzona, czyli tzw. sejsmit.

2. Szczegółowa analiza potencjalnych sejsmitów powinna być prowadzona z uwzględnieniem: analizy litofacjalnej profilu, szczegółowego opisu deformacji (dystrybucji, powtarzalności w pionie, rozciągłości poziomej, typu i geometrii deformacji opisu tekstury i struktury) w obrębie zdeformowanej warstwy, wytypowania struktur, które mogły powstać w efekcie upłynnienia i porównania ich ze współcześnie powstającymi strukturami, rozpoznania budowy geologicznej podłoża skalnego, dyskusji nad pozostałymi mechanizmami, które mogły doprowadzić do powstania deformacji oraz datowania osadów.

3. Zaproponowany schemat badawczy może ułatwić rozpoznanie śladów trzęsień ziemi w przeszłości geologicznej oraz umożliwić określenie ich ewentualnej częstotliwości i zasięgu.

\section{Podziękowania}

Autorzy dziękują recenzentom za trafne uwagi i dyskusję. Prace finansowane były ze środków Narodowego Centrum Nauki 2015/19/B/ST10/00661 (projekt Grebal).

\section{Literatura}

Alfaro P., Delgado J., Estévez A., Molina J., Moretti M., Soria J. 2002. Liquefaction and fluidization structures in Messinian storm deposits (Bajo Segura Basin, Betic Cordillera, southern Spain). International Journal of Earth Sciences 91: 505-513.

Allen J.R.L. 1982. Sedimentary structures, their character and physical basis. Elsevier.

Allen J.R.L. 1986. Earthquake magnitude-frequency epicentral distance and soft-sediment deformation in sedimentary basins. Sedimentary Geology 46: 67-75.

Allen J.R.L. 2003. Load Structures. W: G.V. Middleton (red.) Encyclopedia of sediments and sedimentary rocks. Kluwer Academic Publishers, Dordrecht: 413-414.

Alsop G.I., Marco S. 2011. Soft-sediment deformation within seismogenic slumps of the Dead Sea Basin. Journal of Structural Geology 33: 433-457.

Ambraseys N. 1988. Engineering seismology. Earthquake Engineering \& Structural Dynamics 17: 1-115.

Brandes C., Winsemann J. 2013. Soft-sediment deformation structures in NW Germany caused by Late Pleistocene seismicity. International Journal of Earth Sciences 102: 2255-2274.

Brandes C., Winsemann J., Roskosch J., Meinsen J., Tsukamoto S., Frechen M., Tanner D.C., Steffen H., Wu P. 2012. Activity along the Osning Thrust in Central Europe during the Lateglacial: Ice-sheet and lithosphere interactions. Quaternary Science Reviews 38: 49-62.

Casagrande A. 1976. Liquefaction and cyclic deformation of sands: a critical review. Harvard Soil Mechanics Series 88: 1-26.

Crespellani T., Nardi R., Simoncini C. 1988. La liquefazione del terreno in condizioni sismiche. Zanichelli, Bologna.

Ezquerro L., Moretti M., Liesa C.L., Luzón A., Simón J.L. 2015. Seismites from a well core 
of palustrine deposits as a tool for reconstructing the palaeoseismic history of a fault. Tectonophysics 655: 191-205.

Galli P. 2000. New empirical relationships between magnitude and distance for liquefaction. Tectonophysics 324: 169-187.

Grollimund B., Zoback M. 2000. Post glacial lithospheric flexure and induced stresses and pore pressure changes in the northern North Sea. Tectonophysics 327: 61-81.

Guiraud M., Plaziat J.-C. 1993. Seismites in the fluviatile Bima sandstones: identification of paleoseisms and discussion of their magnitudes in a Cretaceous synsedimentary strike-slip basin (Upper Benue, Nigeria). Tectonophysics 225: 493-522.

Hoffmann G., Reicherter K. 2012. Soft-sediment deformation of Late Pleistocene sediments along the southwestern coast of the Baltic Sea (NE Germany). International Journal of Earth Sciences 101: 351-363.

Jarosiński M. 2010. Recent tectonic stress field investigations in Poland: a state of the art. Geological Quarterly 50: 303-321.

Jaroszewski W., Marks L., Radomski A. 1985. Słownik geologii dynamicznej. Wydawnictwa Geologiczne, Warszawa.

Lowe D.R. 1976. Subaqueous liquefied and fluidized sediment flows and their deposits. Sedimentology 23: 285-308.

McCalpin J.P., Nelson A.R. 2009. Introduction to Paleoseismology. W: J.P. McCalpin (red.) Paleoseismology. Elsevier, Nowy Jork: 1-25.

Miall A.D. 1977. A review of the braided-river depositional environment. Earth Science Reviews 13: 1-62.

Moretti M., Van Loon A.J. 2014. Restrictions to the application of "diagnostic" criteria for recognizing ancient seismites. Journal of Palaeogeography 3: 162-173.

Moretti M., Alfaro P., Caselles O., Canas J.A. 1999. Modelling seismites with a digital shaking table. Tectonophysics 304: 369-383.

Mörner N.-A. 1991. Intense earthquakes and seismotectonics as a function of glacial isostasy. Tectonophysics 188: 407-410.

Mörner N.-A. 2005. An interpretation and catalogue of paleoseismicity in Sweden. Tectonophysics 408: 265-307.

Mörner N.-A. 2013. Patterns in seismology and palaeoseismology, and their application in longterm hazard assessments - the Swedish case in view of nuclear waste management. Pattern Recognition in Physics 1: 75-89.

Obermeier S.F. 1996. Use of liquefaction-induced features for paleoseismic analysis - An overview of how seismic liquefaction features can be distinguished from other features and how their regional distribution and properties of source sediment can be used to infer the locat. Engineering Geology 44: 1-76.

Obermeier S.F. 2009. Using Liquefaction-Induced and Other Soft-Sediment Features for Paleoseismic Analysis. W: J.P. McCalpin (red.) Paleoseismology. Elsevier, New York: 497564.

Obermeier S.F., Olson S.M., Green R.A. 2005. Field occurrences of liquefaction-induced features: A primer for engineering geologic analysis of paleoseismic shaking. Engineering Geology 76: 209-234.

Owen G. 1996. Experimental soft-sediment deformation: Structures formed by the liquefaction of unconsolidated sands and some ancient examples. Sedimentology 43: 279-293.

Owen G., Moretti M. 2008. Determining the origin of soft-sediment deformation structures: a case study from Upper Carboniferous delta deposits in south-west Wales, UK. Terra Nova 20: 237245.

Owen G., Moretti M. 2011. Identifying triggers for liquefaction-induced soft-sediment deformation in sands. Sedimentary Geology 235: 141-147.

Owen G., Moretti M., Alfaro P. 2011. Recognising triggers for soft-sediment deformation: Current understanding and future directions. Sedimentary Geology 235: 133-140.

Papadopoulos G., Lefkopoulos G. 1993. Magnitudedistance relations for liquefaction in soil from earthquakes. Bulletin of the Seismological Society of America 83: 925-938.

Piotrowski A. 1999. Wpływ zróżnicowanego obciążenia strefy krawędziowej lądolodu na migrację soli. Przegląd Geologiczny 47:1016-1021.

Pisarska-Jamroży M., Weckwerth P. 2013. Softsediment deformation structures in a Pleistocene glaciolacustrine delta and their implications for the recognition of subenvironments in delta deposits. Sedimentology 60: 637-665.

Põldsaar K., Ainsaar L. 2015. Soft-sediment deformation structures in the Cambrian (Series 2) tidal deposits (NW Estonia): Implications for identifying endogenic triggering mechanisms in ancient sedimentary record. Palaeoworld 24: $16-35$.

Quigley M.C., Hughes M.W., Bradley B.A., van Ballegooy S., Reid C., Morgenroth J., Horton T., Duffy B., Pettinga J.R. 2016. The 20102011 Canterbury Earthquake Sequence: Environmental effects, seismic triggering thresholds and geologic legacy. Tectonophysics 673: 228-274.

Rodríguez-López J.P., Meléndez N., Soria A.R., Liesa C.L., Van Loon A.J. 2007. Lateral variability of ancient seismites related to differences in sedimentary facies (the synrift Escucha Formation, mid-Cretaceous, eastern Spain). Sedimentary Geology 201: 461-484. 
Rossetti D.D.F. 1999. Soft-sediment deformation structures in late Albian to Cenomanian deposits, Sao Luis Basin, northern Brazil: Evidence for palaeoseismicity. Sedimentology 46: 1065-1081.

Seilacher A. 1969. Fault-graded beds interpreted as seismites. Sedimentology 13: 155-159.

Shanmugam G. 2016. The seismite problem. Journal of Palaeogeography 5: 318-362.

Tian H.S., Van Loon A.J., Wang H.L., Zhang S.H., Zhu J.W. 2016. Seismites in the Dasheng Group: New evidence of strong tectonic and earthquake activities of the Tanlu Fault Zone. Science China Earth Sciences 59: 601-618.

Tian Y., Zhong J.H., Wang S.B., Tao H.S., Liu S.G., Li Y., Ni L. T. 2015. Seismites and their geological significances of the Triassic Yanchang Formation in Fuxian exploration area, Ordos Basin. Journal of Palaeogeography 17: 541552.

Tuttle M.P., Villamor P., Almond P., Bastin S., Bucci G., Langdridge R., Hardwick C.M. 2017. Liquefaction induced during the 2010-2011 Canterbury, New Zealand, Earthquake Sequence and Lessons Learned for the Study of Paleoliquefaction Features. Seismological Research Letters 88: 1403-1414.

Van Loon A.J. 2009. Soft-sediment deformation structures in siliciclastic sediments : an overview. Geologos 15: 3-55.

Van Loon A.J., Maulik P. 2011. Abraded sand volcanoes as a tool for recognizing paleo-earthquakes, with examples from the Cisuralian Talchir Formation near Angul (Orissa, eastern India). Sedimentary Geology 238: 145-155.

Van Loon A.J., Pisarska-Jamroży M. 2014. Sedimentological evidence of Pleistocene earthquakes in NW Poland induced by glacio-isostatic rebound. Sedimentary Geology 300: 1-10.

Van Loon A.J., Pisarska-Jamroży M., Nartišs M., Krievāns M., Soms J. 2016. Seismites resulting from high-frequency, high-magnitude earthquakes in Latvia caused by Late Glacial glacio-isostatic uplift. Journal of Palaeogeography 5: 363-380.

Van Vliet-Lanoë B., Bonnet S., Hallegouët B., Laurent M. 1997. Neotectonic and seismic activity in the Armorican and Cornubian Massifs: Regional stress field with glacio-isostatic influence? Journal of Geodynamics 24: 219-239.

Van Vliet-Lanoë B., Magyari A., Meilliez F. 2004. Distinguishing between tectonic and periglacial deformations of quaternary continental deposits in Europe. Global and Planetary Change 43: 103-127.

Wojewoda J., Rauch M., Kowalski A. 2016. Synsedimentary seismotectonic features in Triassic and Cretaceous sediments of the Intrasudetic Basin (U Devěti kř́žů locality) - regional implications. Geological Quarterly 60: 3553-64.
Wu P., Johnston P. 2000. Can deglaciation trigger earthquakes in N. America? Geophysical Research Letters 27: 1323-1326.

Zieliński T. 1992. Moreny czołowe Polski północnowschodniej - osady i warunki sedymentacji. Prace Nauk. Uniw. Śląskiego, Katowice.

Zieliński T. 1995. Kod litofacjalny i litogenetyczny konstrukcja i zastosowanie. W: E. Mycielska-Dowgiałło, J. Rutkowski (red.) Badania osadów czwartorzędowych. Wybrane metody $i$ interpretacja wyników. Uniwersytet Warszawski, Warszawa: 220-235.

Zieliński T. 2014. Sedymentologia. Osady rzek i jezior. Wyd. Nauk. UAM, Poznań.

Zieliński T., Pisarska-Jamroży M. 2012. Jakie cechy litologiczne osadów warto kodować, a jakie nie? Przeglad Geologiczny 60: 387-397.

Zoback M.D., Grollimund B. 2001. Impact of deglaciation on present-day intraplate seismicity in Eastern North America and Western Europe. Comptes Rendus de l'Academie de Sciences Serie IIa: Sciences de La Terre et Des Planetes 333: 23-34.

\section{Summary}

Seismites are sedimentary rock layers that were entirely deformed by earthquake-induced processes (Seilacher 1969). Seismic deformations can be triggered by a various mechanisms including meteorite impact, volcanic eruption, glacio-isostatic rebound, rapid sediment loading, salt tectonics, mass movement, current and wave action, gas expulsion, and endogenic forces.

To classify the layer as a seismite, it should meet currently established set of recognizing criteria (Owen, Moretti 2008; Owen et al. 2011; Moretti, Van Loon 2014). The basic criterion of the seismic origin is soft-sediment deformation structures occurrence resulting from water-saturated unconsolidated fine-grained clastic sediment liquefaction due to pore pressure increase and shear strength loss. The deformation develop shortly after deposition, before the lithification process begins. Main groups of SSDS are: (1) dewatering structures (water/fluid escape structures); (2) unstable density stratification structures and (3) brittle deformations. The second criterion is the lateral extent of deformation structures along the deformed layer and - if the geological conditions are suitable - correlated deformed layers in different sites in the vicinity of possible earthquake epicenter. It is also important to prove the vertical (sandwiched-like) succession of more than one deformed layer between undeformed layers and to propose faults 
that could have been reactivated causing an earthquake in the vicinity of described site.

Authors suggest to conduct investigation of SSDS layers including: (1) lithofacies analysis; (2) detailed description of deformation structures and host sediments, spatial distribution and heterogenity of deformation structures in the plan view as well as an oblique view; (3) identification of structures that could have been formed during liquefaction process; (4) geological subsurface structure recognition; (5) discussion of all other possible triggers that could have caused sediment deformation; (6) estimation the deformation age based on under- and overlying sediments datings and establishing maximal and minimal age of deformation.

A study of layers with soft-sediment deformation structures resulting in seismite recognition can be used as a tool in palaeoseismology studies of pre-historic earthquakes, theirs recurrence, frequency and extent particularly in an intraplate regions recently considered as aseismic. 